\title{
Management of enterprise development based on adaptive value model in digital conditions
}

\author{
Oksana Pirogova ${ }^{1}$, and Vladimir Plotnikov ${ }^{2, *}$ \\ ${ }^{1}$ Peter the Great St. Petersburg Polytechnic University, Institute of Industrial Management, \\ Economics and Trade, Graduate School of Service and Trade, 29 Polytechnicheskaya str., St. \\ Petersburg, Russia, 195251 \\ ${ }^{2}$ Saint-Petersburg State University of Economics, 21 Sadovaya str., St. Petersburg, Russia, 191023
}

\begin{abstract}
Based on the analysis of the features of changes in the institutional environment, the article analyzes the impact of digitalization on the conditions for the functioning and development of enterprises. The introduction of information technology has an impact on all spheres of activity of enterprises, and also leads to the transformation of relations between the consumer and the supplier of goods or services. The basic concepts of cost management of enterprises are analyzed, the problems of implementing the principles of cost management at domestic enterprises are considered. The analysis of the problems of the cost management introduction at the stages of the life cycle of the enterprise is done. It is proposed to consider the problems of cost management on the basis of a basic generalized model of the enterprise life cycle. It is shown that at various stages of the life cycle, the basic model of dynamic consistency of development indicators can undergo changes. Based on the dynamics of the cash flow and income of the enterprise, depending on the stage of the life cycle, modifications of the basic model of dynamic coordination of enterprises are proposed. The structure of the models, depending on the stage of the life cycle, is determined by the change in target settings in the enterprise. The proposed models can be used to assess the correct implementation of management decisions based on indicators and criteria for the value of the enterprise.
\end{abstract}

\section{Introduction}

The interaction of business, government and the scientific community in Russia begins to be implemented as part of the development of the national program "Digital Economy of the Russian Federation", which is implemented from 2018 to 2024 [1]. The growing digitalization processes are blurring not only geographical, but also physical boundaries, which contributes to the development of business and economies around the world. Digitalization contributes to economic growth and labor productivity, creating innovative jobs and digital assets, expanding the opportunities and rights of citizens, improving access

*Corresponding author: plotnikov_2000@mail.ru 
to global markets and increasing the competitiveness of micro, small and medium enterprises [2].

Digitalization is becoming the main trend, has an impact on the development of enterprises, contributes to dramatic improvements at all stages of its production cycle, and is actively involved in the automation of internal business processes (communication with customers, task distribution within the team, electronic folders, menus, etc.). In addition, digitalization allows to reduce production costs, optimize supply management, which contributes to a faster response to any new consumer needs, including in real time [3]. Customers have a feedback system with the manufacturer, consumer properties and the safety of goods and services are significantly improved due to the digital component, whose contribution to the cost can reach up to half its value [4].

The introduction of information technology provides an opportunity for new operating models and business processes, platforms for connected products, analytics and teamwork to increase productivity. All this has not been available to consumers before. An increase in the volume of available information led to an increase in its quality, which, in turn, led to better consumer awareness [5].

Thanks to the advent of online platforms, sellers and buyers can communicate directly, bypassing intermediaries [6]. Enterprises use information technology as a competitive advantage in all spheres of their activity: production, business processes, marketing and customer interaction [7].

\section{Problems of implementing VBM management}

Currently, cost-based management or VBM management is a relatively young area of management. Value-based management (VBM) is currently a universally recognized concept focused on updating the future value of the company in the process of making current operational and strategic decisions. In contrast to existing management concepts, the concept of value-based management includes a number of fundamental features, which include [8,9]:

- proposes to combine the needs and goals of owners and key stakeholders (managers, workers, contractors) in a single general indicator - the value of the enterprise;

- shifts emphasis in making managerial decisions from the past and present to the future, i.e. the cost approach allows you to balance the benefits of different periods and abandon current profits in favor of future;

- allows you to find a compromise between sales volumes and their profitability, profitability and turnover, profit and capital costs;

- based on known information about the activities of the enterprise and the functioning of all markets;

- allows you to correctly pose questions of strategic management and critically evaluate the results of their use.

The basic concepts and cost indicators that have received the recognition of specialists are presented in table. 1 [10]

Analysis of management concepts shows that the most appropriate is the management concept based on the cost approach, which takes into account not only market assessments, but also the quality of management in the enterprise. The introduction of this concept into the activities of modern domestic enterprises meets the following serious difficulties [11]:

- the methodological approaches developed to date and economic models are intended mainly for large enterprises, however, for medium and small enterprises this concept remains inapplicable;

- indicators for assessing the value of an enterprise or its growth take various forms and are often not comparable; 
- most of the indicators for assessing growth in value are a commercial product; they contain in the methodology of their application a number of patented and protected knowhow that are known only to the manufacturer. In addition, the introduction of such products requires significant organizational and financial costs, including the adaptation of the product to a specific enterprise, as well as the maintenance of a commercial product.

Table 1. the Content of the basic concepts of management based on VBM.

\begin{tabular}{|c|c|c|}
\hline Concept name & Indicator & Content of the approach \\
\hline $\begin{array}{c}\text { A. Rappaport } \\
\text { Shareholder Value } \\
\text { Added Concept }\end{array}$ & $\begin{array}{l}\text { SVA (shareholder } \\
\text { value added) }\end{array}$ & $\begin{array}{c}\text { assessment of the effectiveness of the investment } \\
\text { and financial strategies of corporations based on } \\
\text { its ability to create shareholder value }\end{array}$ \\
\hline $\begin{array}{l}\text { Stern, Steward } \\
\text { The concept of } \\
\text { economic value added }\end{array}$ & $\begin{array}{l}E V A \text { (economic value } \\
\text { added) }\end{array}$ & $\begin{array}{l}\text { According to the EVA concept, business value is } \\
\text { the carrying amount increased by the present } \\
\text { value of future value added. Stern Stewart proves } \\
\text { correlation between EVA and market value }\end{array}$ \\
\hline $\begin{array}{c}\text { Stern, Steward } \\
\text { The concept of market } \\
\text { value added }\end{array}$ & $\begin{array}{l}M V A \text { (market value } \\
\text { added) }\end{array}$ & $\begin{array}{c}\text { The difference between the total value of the } \\
\text { company and the total amount of capital } \\
\text { employed (including equity and debt). Reflects } \\
\text { the present value of all present and future } \\
\text { investments }\end{array}$ \\
\hline $\begin{array}{l}\text { Copeland, Koller, } \\
\text { Murrin } \\
\text { Concept of value } \\
\text { thinking } \\
\end{array}$ & & $\begin{array}{l}\text { allows you to take into account intangible assets } \\
\text { that are not reflected in the balance sheet, which } \\
\text { at the present stage have particular importance in } \\
\text { the activities of companies }\end{array}$ \\
\hline $\begin{array}{l}\text { Levis } \\
\text { Value added concept }\end{array}$ & $\begin{array}{l}C V A \text { (currency value } \\
\text { added) }\end{array}$ & $\begin{array}{l}\text { the idea of the concept is the assertion that not } \\
\text { only shareholders, but also other stakeholders } \\
\text { should benefit from increasing the value of the } \\
\text { company }\end{array}$ \\
\hline $\begin{array}{c}\text { Model EBO (Edward- } \\
\text { Bell-Olson })\end{array}$ & $\begin{array}{c}\text { Formula for } \\
\text { calculating cost based } \\
\text { on autoregression }\end{array}$ & $\begin{array}{l}\text { business value is determined on the basis of } \\
\text { discounting excess profits }\end{array}$ \\
\hline
\end{tabular}

\section{Problems of implementing VBM at the stages of the enterprise life cycle}

Currently, the cost approach seems to be the most progressive approach, which allows you to plan and evaluate the activities of the enterprise based on an integrated indicator - cost. One of the problems of implementing VBM is not taking into account the stages of the life cycle of an enterprise when determining value [12]. Life cycle models of enterprise development are quite widespread in modern management. The practical significance of these models is due to the need to further improve business processes, to obtain the possibility of an adequate response to external and internal changes, as well as to increase flexibility in the process of enterprise development [13]. The main task of life cycle models is to periodize the stages of enterprise development, formalize them in order to determine the leading factors of development, driving forces at each stage, as well as development problems that are considered in these models as crises or "traps". This approach allows not only to specify management efforts, but also to modify the financial model of the enterprise in the process of its development [14].

In order to prevent financial crises, it is necessary to constantly monitor the results of financial activities and financial indicators of the company's condition, on the basis of which it is possible to adjust the applied financial strategy, policy and specific measures. 
Depending on the stage of the enterprise life cycle, the following financial strategies are proposed in [15]:

- at the stage of creation - investment strategy, depending on the depth of development and attractiveness of the business idea;

- at the stage of formation - budgeting strategy that helps to clearly allocate resources in accordance with the company's mission;

- at the growth stage-a lending and investment strategy that ensures an optimal level of own and borrowed funds;

- at the stage of maturity, these are strategies for reducing costs and optimizing the use of free cash resources of the enterprise.

- at the stage of decline-a strategy for financing innovation or a strategy for increasing the value of the enterprise for its successful sale.

Among all the models, the most popular are the Adizes I. life cycle models and the Greiner L. enterprise development model. The life cycle model, which is called the "Dynamic (organic) enterprise development model", developed by scientists such as Glasl, F. and Lievegoed, B. is also of interest [16]. A comparison of different life cycle models shows that at the heart of any of the proposed models a number of basic stages can be distinguished that are in any model, while the difference between the models often lies in a more detailed and deep division of the individual stages of the life cycle due to the orientation when analyzing certain aspects of enterprises activity [17].

The basic model of the enterprise life cycle can be represented in the form of the following main stages: birth, youth (rapid growth), maturity (flowering), crisis. Further, two possible outcomes are assumed - withering and death, or a new stage of development, which can be implemented through the association phase and is provided due to external opportunities that open to the enterprise [18]. The main objective of the life cycle models is to periodize the stages of enterprise development, formalize them in order to determine the leading development factors, driving forces at each stage, therefore this approach allows not only to specify the management efforts, but also to modify the financial model of the enterprise during its development [19]. To assess the activities of the enterprise at various stages of development, the use of various financial indicators is necessary. As a rule, these include: minimum capital investment for a given result; maximum reduced profit; maximum current costs; minimum time for capital turnover; maximum return on equity [20].

\section{Development of a life-cycle model for enterprise value management}

We propose to use the life cycle model to manage the value of the enterprise [21]. The main idea of the approach is that at different stages of the life cycle of an enterprise, the dynamics of the components of value are different, and this must be taken into account when constructing a system for managing the development of an enterprise based on value [22]. But since the indicator of value, as an economic category, is heterogeneous, therefore, a model of the fundamental value of the enterprise is proposed, including the balance sheet, operational, investment levels and the level of value of dynamic flexibility [23]. Each level has its own characteristics associated with the manifestation, assessment methods and ways of managing this component of value [24]. The indicator of growth in the value of the enterprise, determined through cash flows, is determined by the complex internal structure of the value generation system and is formed by cash flows from the operating, investing and financing activities of the enterprise. The dynamics of these components of the cash flow and the integrated value of the net cash flow of the enterprise are presented in Fig. 1. 
To assess each component of value, a chain of indicators can be used that characterize the value and quality of one or another component of value. In general, these indicators can be combined into a system based on the principles of dynamic consistency. The base chain is the dynamic coordination of individual elements of fundamental value:

$$
I\left(V_{D F}\right)>I\left(V_{I}\right)>I\left(V_{O}\right)>I\left(V_{B}\right)>0
$$

where $I\left(V_{B}\right)$ - growth rate of the balance component of the trading company fundamental value;

$I\left(V_{O}\right) \quad$ - growth rate of the operating component of the trading company fundamental value;

$I\left(V_{I}\right) \quad$ - growth rate of the investment component of the trading company fundamental value;

$I\left(V_{D F}\right)$ - growth rate of the component of dynamic flexibility (potential) of the trading company fundamental value.

Such a representation of value may not always reflect the urgent needs of the enterprise at the current stage of the life cycle. At each stage of the life cycle, it is possible to build your own ordering system, which will allow company management to more accurately select mechanisms for influencing the rate of cost growth. Therefore, it is proposed to transform the basic dynamic ordering equation (1) for various stages of the life cycle.

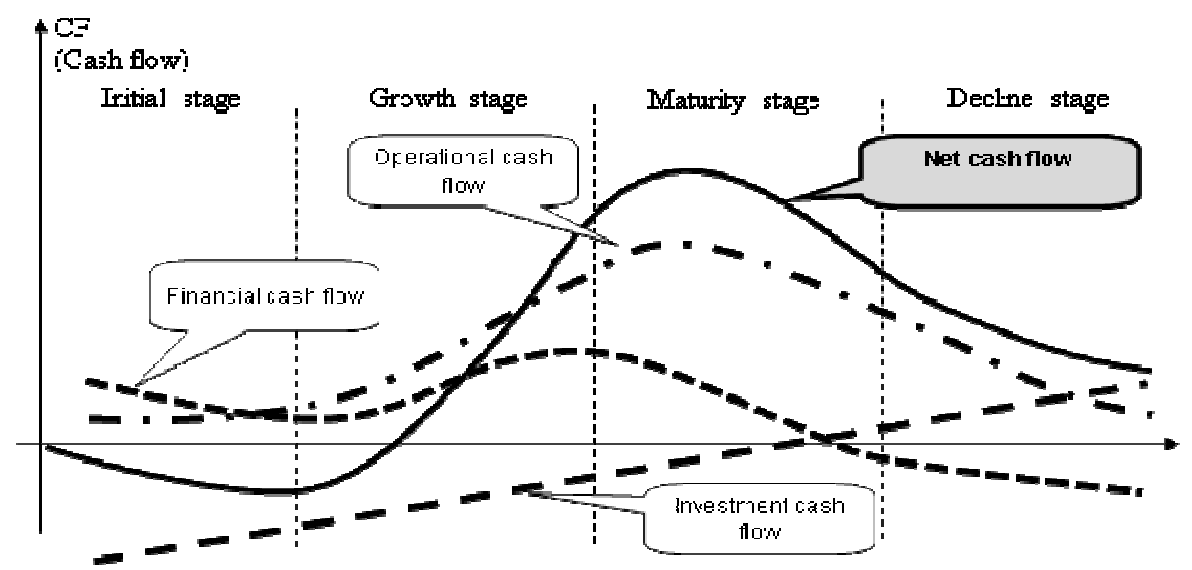

Fig. 1. The dynamics of cash flow and its components at the stages of the life cycle of the enterprise.

At the inception stage, the main task of the enterprise is to ensure the viability of the business project. At this stage of development, the enterprise is experiencing a shortage of financial resources; therefore, a business liquidity crisis and an owner's liquidity crisis may occur. Therefore, efforts should be aimed at making the company work, and all management efforts should be directed at managing the increase in the operating value of the company. Such a control strategy corresponds to the following dynamic ordering equation:

$$
I\left(V_{O}\right)>0
$$

At this stage, the management of such cost components as investment and the component of dynamic flexibility in principle is not carried out. 
At the stage of youth, the main task of enterprise management is the transformation of cash flow into an established market share. At this stage, the company requires significant financial resources, as its own financial resources that the company generates are insufficient. Thus, to ensure the growth of the book value, it is necessary to include the tasks of managing the investment component of the cost, which is aimed at the growth of the main activity of the enterprise (investment in the main activity of the enterprise). On the other hand, at this stage the problem of managing the balance component of the cost arises, it manifests itself, inter alia, in maintaining the optimal capital structure of the growing enterprise. Therefore, the main problems at this stage are the rapid growth of operating cash flow and operating component of the cost, providing financing for the growth of the enterprise (the investment component of fundamental value, but mainly in current assets), as well as ensuring an acceptable capital structure, which in turn affects the amount balance component of the fundamental value of the enterprise. The dynamic consistency profile at this stage may have the following form:

$$
I\left(V_{O}\right)>I\left(V_{I}\right)>I\left(V_{B}\right)>0 .
$$

The next stage is the stage of prosperity and stability. This stage is characterized by high competition. An enterprise can survive either by building an effective business model, or by continuously increasing efficiency. The main objective of this stage is to increase efficiency. In order to ensure competitiveness, an enterprise begins to invest in ensuring its dynamic flexibility, costs for intellectual capital arise, intangible assets, network capital are formed. At the initial stage of the stability stage, the following form of dynamic coordination should be carried out, while the intensity of operating activities may still exceed the intensity of investment activities:

$$
I\left(V_{O}\right)>I\left(V_{I}\right)>I\left(V_{B}\right)>I\left(V_{D F}\right)>0,
$$

At the end of the heyday, priorities change. This is due to the fact that, despite the sufficient market efficiency of the main activity of the enterprise, having exhausted the rapid growth rate, it is increasingly reducing its effectiveness. This leads to an increase in the role of investments, therefore, the growth rate of the investment component of value at some point in time should exceed the growth rate of the operating component of value (which may decrease at this stage), the cost of dynamic flexibility should increase at a faster rate, due to the growth of intellectual, social network and other types of capital (see Fig. 2).

The increase in this component of value is especially relevant at this stage of development due to the urgent need for future transformations of the enterprise. The equation of dynamic consistency at this stage of the life cycle has the following form:

$$
I\left(V_{D F}\right)>I\left(V_{I}\right)>I\left(V_{O}\right)>I\left(V_{B}\right)>0,
$$

Thus, only at its heyday is an ideal dynamic ordering of cost components achieved from an economic point of view.

If the company copes with the problems of reorienting the business to new key competencies, then the growth stage should begin again, which is described by inequality (3). If the decline begins and the death of the enterprise is planned, then it becomes very difficult to specify the form of expressing the dynamic consistency of the growth rates of the cost components, primarily due to a decrease in the financial and economic performance of the enterprise. 


\section{Conclusion}

Based on the use of the enterprise life cycle model and the analysis of problems in creating enterprise value, various profiles of dynamic consistency of basic indicators of fundamental value are proposed, which allow taking into account the unevenness of the magnitude and dynamics of the components of fundamental value in the process of enterprise development. This allows enterprises to focus on the most important aspects of value creation depending on the stage of the enterprise's life cycle, to correctly prioritize the development of a financial interest system when introducing a cost approach, and also to avoid the errors of premature or, conversely, belated implementation of certain aspects of cost management. The approach considered in the article can also be useful in identifying the current stage of the enterprise life cycle.

\section{References}

1. O. Pirogova, E. Gorin, V. Plotnikov, E3S Web of Conferences 91, 08021 (2019)

2. V. Plotnikov, O. Pirogova, Key Competencies as an Enterprise Value Management Tool, IBIMA 2018, 1716-1721 (2018)

3. M. Ardolino, M. Rapaccini, N. Saccani, P. Gaiardelli, G. Crespi, C. Ruggeri, Journal of Production Research, 56(6), 2116-2132 (2018). DOI 10.1080/00207543.2017.1324224

4. J. H. Dyer, H. Singh, W. S. Hesterly, Strategic Management Journal 39(12), 3140-3162 (2018). DOI 10.1002/smj.2785

5. J.A. Ohlson, Contemporary Accounting Research 11(2), 661-687 (1995)

6. L.E. Greiner, Harvard Business Review 50(4), 37-46 (1972)

7. E. Edwards, P. Bell, The Theory and Measurement of Business Income (University of California Press, 1961)

8. I. Adizes, Corporate Lifecycles: how and why corporations grow and die and what to do about it. Englewood Cliffs (N.J., Prentice Hall, 1988)

9. T. Copeland, T. Koller, J. Murrin, Valuation: Measuring and Managing the Value of Companies (New York, McKinsey \& Company Inc. 1996)

10. A. Rappaport, Journal of Business Strategy 2, 14-28 (1986).

11. C. Gronroos, Marketing Theory 11, 279-301 (2011). DOI 10.1177/1470593111408177

12. S. Lenka, V. Parida, J. Wincent, Psychology \& Marketing 34(1), 92-100 (2017). DOI 10.1002/mar.20975

13. M. Martín-Peña, J. Sánchez-López, E. Díaz-Garrido, Journal of Business \& Industrial Marketing 35(3), 564-574 (2019). DOI 10.1108/JBIM-12-2018-0400

14. D. Sjödin, V. Parida, M. Jovanovic, I. Visnjic, Journal of Product Innovation Management 37(2), 158-183 (2020). DOI 10.1111/jpim.12516

15. E. Fang, W.R. Palmatier, J.-B.E. Steenkamp, Journal of Marketing 72, 1-14 (2008). DOI 10.1509/jmkg.72.5.1

16. M. M. Hasan. Journal of Contemporary Accounting \& Economics 13, 20-36 (2017). DOI: $10.1016 /$ j.jcae.2017.01.002

17. K.M. Bakarich, M. Hossain, J. Weintrop, Journal of Contemporary Accounting \& Economics 15(1), 69-86 (2019). DOI 10.1016/j.jcae.2018.12.002

18. J. Stern, G. Stewart, D. Chew, Journal of Applied Corporate Finance 8(2), 32-46 (1995). DOI: $10.1111 / \mathrm{j} .1745-6622.1995 . t b 00285 . x$. 
19. A.R. Bril, O.V. Kalinina, O.V. Rasskazova, IBIMA 2018, 5772-5782 (2018).

20. S. Barykin, S. Gazul, V. Kiyaev, O. Kalinina, V. Yadykin, International Scientific Siberian Transport Forum, 844-852 (Springer, Cham, 2019)

21. O. Pirogova, V. Plotnikov, International Scientific Siberian Transport Forum, 738-747 (Springer, Cham, 2019). DOI 10.1007/978-3-030-37919-3 73

22. A. Eggert, J. Hogreve, W. Ulaga, E. Muenkhoff, Journal of Service Research 17(1), 23 39 (2014). DOI: 10.1177/1094670513485823

23. E. Brynjolfsson, L. M. Hitt, Journal of Economic Perspectives 14(4), 2000, 23-48. DOI 10.1257/jep.14.4.23

24. C. Kowalkowski, H. Gebauer, R. Oliva, Industrial Marketing Management 60, 82-88 (2017). DOI 10.1016/j.indmarman.2016.10.015 